\title{
Manajemen Keuangan dan Pembiayaan (Tamwil) Dalam Perspektif Islam
}

\author{
Nur Khomisah Pohan \\ UIN Sunan Kalijaga Yogyakarta, Indonesia \\ Email: nurkhomisahpohan@gmail.com

\section{Hellen Tiara} \\ UIN Sunan Kalijaga Yogyakarta, Indonesia \\ Email: hellentiara@gmail.com
}

DOI: https://doi.org/10.21154/sajiem.v3i1.9o

\begin{abstract}
This study aims to determine financial management and financing (tamwil) in an Islamic perspective. The method used is a library research method, while data collection is carried out by reviewing and exploring several journal articles, books and several other sources of data or information that are considered relevant to this study. The results of this study are that education financing is mainly focused on efforts to spread the benefits of education and the burden that must be borne by the community. The amount of money spent or services offered to students are simply referred to as fees. The allocation of the tax burden in different types of group taxes, as well as the manner in which taxes are sent to schools, are all aspects of financing education. The most important thing in funding education is the amount of money to be spent, where the money should be obtained, and to whom the money should be spent.
\end{abstract}

Keywords: Financial Management, Financing (Tamwil), Islamic Perspective 


\begin{abstract}
Abstrak
Penelitian ini bertujuan untuk mengetahui manajemen keuangan dan pembiayaan (tamwil) dalam perspektif Islam. Metode yang digunakan adalah metode kajian pustaka (library reseach) sedangkan pengumpulan data dilakukan dengan menelaah dan mengeksplorasi beberapa artikel jurnal, bukubuku dan beberapa sumber data atau informasi lainnya yang dianggap relevan dengan kajian ini.Adapun hasil dari penelitian ini adalah bahwa Pembiayaan pendidikan terutama difokuskan pada upaya penyebaran manfaat pendidikan dan beban yang harus ditanggung masyarakat.Jumlah uang yang dikeluarkan atau layanan yang ditawarkan kepada siswa secara sederhana disebut sebagai biaya. Alokasi beban pajak dalam berbagai jenis pajak kelompok manusia, serta cara mengirimkan pajak ke sekolah, adalah semua aspek pembiayaan pendidikan. Yang paling penting dalam mendanai pendidikan adalah jumlah uang yang harus dikeluarkan, ke mana uang itu harus diperoleh, dan kepada siapa uang itu harus dibelanjakan.
\end{abstract}

Keywords: Manajemen Keuangan, Pembiayaan (Tamwil), Perspektif Islam

\title{
Pendahuluan
}

Al-Qur'an adalah sumber informasi utama umat Islam, dan berfungsi sebagai "hudan" yang diisi dengan beragam arahan bagi umat manusia untuk menjadi khalifah yang unggul di planet ini. ${ }^{1}$ Kajian terhadap kandungan AlQur'an mencakup topik yang luas, mulai dari masalah yang telah terjadi, sedang terjadi, atau yang belum terjadi.Al-Qur'an telah menulis tentang berbagai persoalan, mulai dari asal muasal peristiwa manusia hingga aktivitas manusia yang berkaitan dengan manajemen pendidikan dalam situasi ini.

Tidak hanya Al-Qur'an, tetapi juga tindakan, perkataan, dan perbuatan Nabi Muhammad.Hal ini juga dijadikan sebagai acuan dalam kehidupan umat Islam, baik dalam hal hubungan dengan Tuhan, sesama manusia, maupun alam.Ini disebut sebagai hadits.Al-Qur'an dan hadits dianggap mengandung prinsip-prinsip dasar yang berlaku untuk semua aspek kehidupan manusia.

Studi Islam dan ilmu-ilmu lainnya, termasuk manajemen pendidikan Islam, didasarkan pada Al-Qur'an.Tidak ada kesulitan yang tidak dibahas AlQur'an, termasuk masalah manajemen pendidikan Islam. Berikut firman Allah SWT dalam Surah An-Nahl (16) ayat 89:

\footnotetext{
${ }^{1}$ Sugeng Kurniawan, “Konsep Manajemen Pendidikan Islam Dalam Perspektif Al-Qur'an Dan Al-Hadist," Nur El-Islam 2, no. 2 (2015): 1.
} 


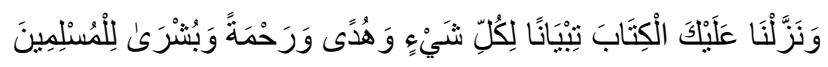

Artinya: Dan kami turunkan Kitab (Al-Qur'an) kepadamu untuk menjelaskan segala sesuatu, sebagai petunjuk, serta rahmat dan kabar gembira bagi orang yang berserah diri. ${ }^{2}$

Keuangan dan pendanaan di sekolah/madrasah merupakan bagian penting dari produksi, karena menjamin terlaksananya kegiatan belajarmengajar, serta komponen lainnya. Dengan kata lain, setiap kegiatan pendidikan pasti melibatkan pengeluaran, baik disadari maupun tidak. Komponen keuangan dan keuangan ini harus dikelola seefisien mungkin agar dapat memaksimalkan penggunaan uang saat ini untuk mendukung tujuan pendidikan.

Pembiayaan pendidikan merupakan salah satu kajian dalam administrasi pendidikan yang mengkaji bagaimana uang tersebut dikumpulkan, bagaimana penggunaannya, dan bagaimana pertanggungjawabannya. Pendapatan (sumber dana), pengeluaran (alokasi penggunaan dana yang dikumpulkan dan dipertanggungjawabkan (accountability), dan penggunaan dana tersebut merupakan tiga bagian dari keuangan pendidikan. ${ }^{3}$ Oleh karena itu, penulis akan mencoba mengulas kembali modul tentang pengelolaan keuangan dan pembiayaan (tamwil) dari perspektif Islam agar lebih mudah bagi kita untuk memahami bagaimana menangani keuangan dan pembiayaan dengan benar dan bertanggung jawab.

\section{Metode Penelitian}

Artikel ini ditulis dengan metode kajian pustaka (Library Research). Data yang digunakan sebagai sumber penulisan berupa buku-buku, artikel, dan beberapa sumber data atau informasi lainnya yang dianggap relevan dengan kajian. Sedangkan dalam menganalisis data penulis menggunakan metode analisis deskriptif.

\section{Temuan dan Pembahasan}

\section{Pengertian Manajemen Keuangan}

Manajemen keuangan syariah adalah suatu proses atau kerangka untuk perolehan, pembiayaan/pembiayaan, dan pengelolaan aset yang berupaya untuk memenuhi tujuan organisasi dengan berpegang pada prinsip dan nilainilai agama dan tauhid, atau sesuai dengan ajaran Islam (Al-Qur'an dan Hadits). ). Semua operasi atau kegiatan organisasi yang bertujuan untuk mendapatkan uang yang diperlukan dan memanfaatkan uang tersebut sebaikbaiknya.

\footnotetext{
${ }^{2}$ Al-Mujib, Al-Qur'an Dan Terjemahannya (Bandung: AL-Mizan, 2012).

${ }^{3}$ Rahmad Hidayat and Candra Wijaya, Ayat-Ayat Al-Qur'an Tentang Manjemen Pendidikan Islam (Medan: LPPPI, 2017).
} 
Manajemen keuangan adalah pengelolaan uang dalam suatu organisasi, baik itu instansi pemerintah, sekolah, rumah sakit, bank, perusahaan, atau entitas lain. Selanjutnya, manajemen keuangan adalah proses pengambilan keputusan yang menggunakan data akuntansi untuk membantu perusahaan dalam mencapai tujuan mereka. ${ }^{4}$

Semua operasi organisasi yang terhubung untuk memperoleh keuangan dan mengelola aset sesuai dengan tujuan organisasi secara keseluruhan disebut sebagai manajemen keuangan. ${ }^{5}$ Manajemen keuangan, di sisi lain, didefinisikan oleh Taufiqurokhman sebagai proses perencanaan, penganggaran, pengecekan, pengelolaan, pengaturan, penugasan, dan penyimpanan kas yang dikendalikan oleh suatu organisasi atau perusahaan. ${ }^{6}$

Selanjutnya, kegiatan pengelolaan keuangan meliputi perolehan dan penetapan sumber dana, pelaporan, penggunaan dana, pemeriksaan, dan pertanggungjawaban, menurut Muh. Hambali dan Mualimin. Pengelolaan keuangan secara keseluruhan adalah rangkaian kegiatan untuk mengatur atau mengelola dana sekolah, yang meliputi pencatatan, perencanaan, pelaksanaan, dan pertanggungjawaban. ${ }^{7}$

Berdasarkan beberapa sudut pandang di atas, manajemen keuangan dapat didefinisikan sebagai "segala tindakan atau kegiatan organisasi yang berkaitan dengan cara mendapatkan sumber dana, menggunakan atau mengalokasikan kas, dan mengelola aset yang dimiliki guna memenuhi tujuan utama organisasi".

Tahapan pengelolaan keuangan meliputi perencanaan keuangan (budgeting), pelaksanaan (accounting), dan penilaian atau evaluasi (audit). ${ }^{8}$

1. Penganggaran (Budgeting)

Suatu metode atau kegiatan untuk membuat anggaran disebut penganggaran.Anggaran adalah rencana bisnis kuantitatif yang dinyatakan dalam satuan moneter yang

\footnotetext{
${ }^{4}$ Rusdiana Navlia Khulaisie, Marketing Off Islamic Education 4.0 Buku Wajib Bagi Para Marketer Pendidikan (Madura: Duta Media, 2019).

${ }^{5}$ Khulaisie.

${ }^{6}$ Taufiqurrokhman, Mengenal Manajemen Sumber Daya Manusia (Jakarta: Fakultas Ilmu Sosial dan Ilmu Politik Universitas Prof.Dr. Moetopo beragama, 2009).

${ }^{7}$ Muh. Hambali and Mualimin, Manajemen Pendidikan Islam Kontemporer (Yogyakarta: IRCiSoD, 2020).

${ }^{8}$ Hidayat and Wijaya, Ayat-Ayat Al-Qur'an Tentang Manjemen Pendidikan Islam.
} 
berfungsi sebagai pedoman untuk melaksanakan kegiatan kelembagaan selama periode waktu tertentu. ${ }^{9}$ Menurut Siegel dan Marcy dari Asnawi, proses penganggaran terdiri dari tiga tahap utama:

a. Menetapkan Tujuan: Langkah pertama dalam perencanaan adalah menerjemahkan tujuan organisasi yang luas ke dalam tujuan kegiatan yang spesifik.

b. Implementasi: Rencana formal digunakan dalam fase implementasi untuk menjelaskan tujuan dan strategi organisasi, serta untuk melibatkan karyawan secara positif.

c. Kontrol dan Evaluasi Kinerja: Setelah anggaran ditetapkan, anggaran menjadi komponen penting dari sistem kontrol, yang berfungsi sebagai dasar terhadap manajemen kinerja aktual dan landasan untuk mengelola dengan pengecualian. ${ }^{10}$

Berikut ini adalah beberapa prinsip Hukum Ekonomi Islam yang dapat diterapkan dalam penganggaran:

a. Pengertian tauhid (Persatuan/Ilahiyah/Ketuhanan) merupakan dimensi vertikal yang menunjukkan bahwa Allah SWT memberikan hidayah (petunjuk) yang benar. Mungkin inilah faktor pendorong yang mendorong kohesi masyarakat, karena semua orang dianggap sama di mata Allah SWT. Tidak ada yang berhak memperbudak orang lain, jadi manusia juga bebas. Semua Muslim berbagi konsep ini, dan sebagai hasilnya, mereka dapat menginspirasi orang untuk melakukan tindakan sosial yang positif atas kemauan mereka sendiri." Prinsip ini diambil dari firman Allah QS. Ali Imran (3) ayat 64.

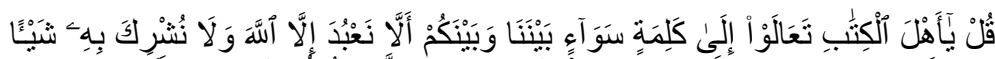

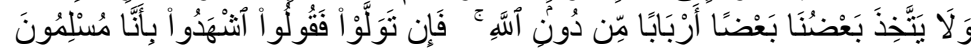
Artinya: Katakanlah (Muhammad), "Wahai Ahli Kitab, marilah (kita) menuju kepada satu kalimat (pegangan) yang sama-sama antara kami dan kamu, bahwa kita tidak menyembah selain Allah dan kita tidak mempersekutukannya dengan satupun, dan bahwa kita tidak menjadikan satu sama lain tuhan-tuhan selain Allah.

\footnotetext{
${ }^{9}$ Ahmad Qurtubi, Administrasi Pendidikan (Tinjauan Teori Dan Implementasi) (Surabaya: Anggota IKAPI, 2019).

${ }^{10}$ Abdul Kadir Arno, "Penyusunan Anggaran Perspektif Fighi Anggaran Hukum Ekonomi Syari'ah Dalam Al-Anwal," Journal Off Islamic Economic Law 1, no. 1 (2016).

${ }^{11}$ Anita Rahmawaty, "Distribusi Dalam Ekonomi Islam Upaya Pemerataan Kesejahteraan Melalui Keadilan Distributif" 1, no. 1 (n.d.): 9.
} 
Jika mereka berpaling maka katakanlah (kepada mereka), "Saksikanlah, bahwa kami adalah orang muslim".

Penerapan hukum ekonomi Islam adalah ibadah, sesuai dengan premis tauhid. Alhasil, bagi seorang muslim yang bekerja keras menyusun anggaran tidak lebih dari beribadah dan menjalankan perintah atau ketetapan Allah SWT, sehingga menghasilkan anggaran yang transparan, akuntabel, disiplin, dan bertanggung jawab.

b. Prinsip keadilan (Equilibrium/ keseimbangan), adalah prinsip yang menuntut terwujudnya keseimbangan individu dan masyarakat, prinsip tersebut menghendaki jalan lurus dengan menciptakan tatanan sosial yang menghindari perilaku merugikan. ${ }^{13}$ Ringkasan kebanyakan ajaran moral Islam memiliki kesamaan atau keseimbangan, termasuk distribusi kekayaan dan pendapatan, kewajiban untuk membantu orang miskin dan yang membutuhkan, dan kebutuhan untuk menyesuaikan ruang lingkup distribusi, hubungan produksi dan konsumsi, dll. ${ }^{14}$ Prinsip keadilan ini diambil dari QS. Al An'am (7) ayat 152.

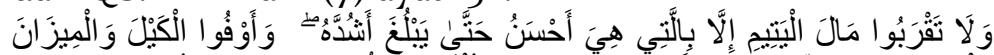

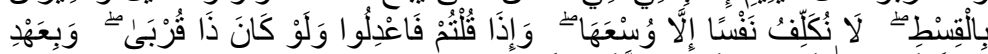

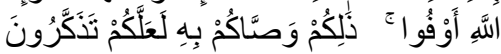

Artinya: Dan janganlah kamu dekati harta anak yatim, kecuali dengan cara yang lebih bermanfaat. Sampai dia mencapai (usia) dewasa. Dan sempurnakanlah takaran dan timbangan dengan adil.Kami tidak membebani sesorang melainkan menurut kesanggupannya.Apabila kamu berbicara, berbicaralah sejujurnya, sekalipun dia kerabat (mu) dan penuhilah janji Allah.Demikianlah Dia memerintahkan kepadamu agar kamu ingat. ${ }^{15}$

c. Prinsip Amar Makruf Nahi Munkar, adalah prinsip yang memposisikan anggaran sebagai pedoman kerja, sehingga bagi yang melakukan penyimpangan (kemungkaran) dapat diberi sanksi, dan yang berprestasi dapat diberi

\footnotetext{
${ }^{12}$ Al-Mujib, Al-Qur'an Dan Terjemahannya.

${ }^{13} \mathrm{Al}-\mathrm{Mujib}$.

${ }^{14}$ Rahmawaty, "Distribusi Dalam Ekonomi Islam Upaya Pemerataan Kesejahteraan Melalui Keadilan Distributif."

${ }^{15} \mathrm{Al}-\mathrm{Mujib}$, Al-Qur'an Dan Terjemahannya.
} 
rewards. ${ }^{16}$ Prinsip Amar ma'ruf nahi mungkar tersebut ditegaskan dalam QS. Ali Imran (3) ayat 104, 110 dan 114.

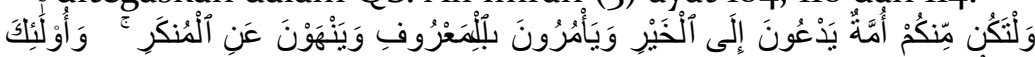

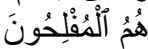

Artinya: Dan hendaklah di antara kamu ada segolongan orang yang menyeru kepada kebaikan, menyuruh (berbuat) yang makruf, dan mencegah dari yang mungkar. Dan mereka itulah orang_orang yang beruntung. ${ }^{17}$

d. Prinsip pertanggungjawaban (responsibility), adalah prinsip yang menuntut komitmen mutlak terhadap upaya peningkatan kesejahteraan sesama manusia, sehingga penyusunan anggaran harus dipertanggungjawabkan kebenarannya. ${ }^{18}$ Prinsip pertanggungjawaban tersebut ditegaskan dalam QS. Al-Isra (15) ayat 36 dan surah alahzab ayat 15 .

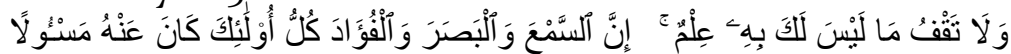
Artinya: Dan janganlah kamu mendekati harta anak yatim, kecuali dengan cara yang lebih baik (bermanfaat) sampai dia dewasa, dan penuhilah janji, karena janji itu pasti diminta pertanggungjawabannya. ${ }^{19}$

2. Pelaksanaan (Akunting)

Akuntansi adalah bahasa yang digunakan untuk menggambarkan hasil kegiatan ekonomi. Menurut Mulyasa, pelaksanaan keuangan sekolah secara garis besar dapat dibedakan menjadi dua kegiatan, yaitu pendapatan dan belanja. Pendapatan keuangan sekolah dari sumber pendanaan harus dicatat sesuai dengan kesepakatan yang disepakati, termasuk konsep teoritis dan prosedur pengelolaan peraturan pemerintah. ${ }^{20}$ Allah Swt. menjelaskan didalam Al-Qur'an Surat Al-Baqarah (2) Ayat 282 yang berbunyi:



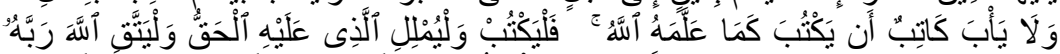

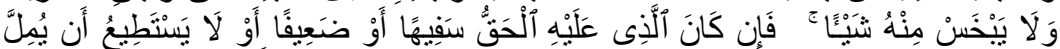

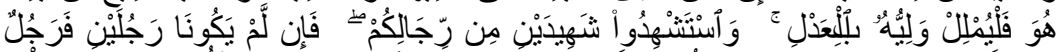

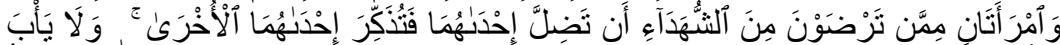

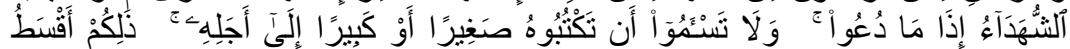

\footnotetext{
${ }^{16}$ Hidayat and Wijaya, Ayat-Ayat Al-Qur'an Tentang Manjemen Pendidikan Islam.

${ }^{17}$ Al-Mujib, Al-Qur'an Dan Terjemahannya.

${ }^{18}$ Arno, "Penyusunan Anggaran Perspektif Fiqhi Anggaran Hukum Ekonomi Syari'ah Dalam Al-Anwal."

${ }^{19}$ Al-Mujib, Al-Qur'an Dan Terjemahannya.

${ }^{20}$ Hidayat and Wijaya, Ayat-Ayat Al-Qur'an Tentang Manjemen Pendidikan Islam.
} 


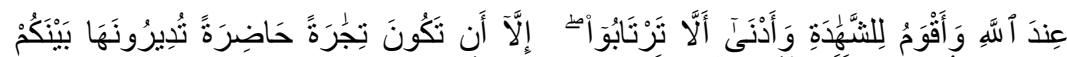

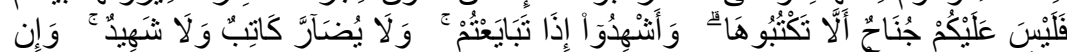

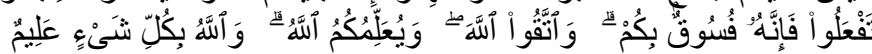

Artinya: Wahai orang-orang yang beriman! Apabila kamu melakukan hutang piutang untuk waktu yang ditentukan, hendaklah kamu menuliskannya.Dan hendaklah seorang penulis di antara kamu menuliskannya dengan benar.Janganlah penulis menolak untuk menuliskannya sebagaimana Allah telah mengajarkan kepadanya, maka hendaklah dia menuliskan.Dan hendaklah orang yang berhutang itu mendiktekan, dan hendaklah dia bertakwa kepada Allah, Tuhannya, dan janganlah dia mengurangi sedikitpun daripadanya. Jika yang berhutang itu orang yang kurang akalnya atau lemah (keadaannya) atau tidak mampu mendikte kan sendiri, maka hendaklah walinya mendiktekan nya dengan benar. Dan persaksikanlah dengan dua orang saksi laki-laki di antara kamu. Jika tidak ada (saksi) dua orang laki-laki maka boleh seorang laki-laki dan 2 orang perempuan di antara orang-orang yang kamu sukai dari para saksi (yang ada), agar jika yang seorang lupa maka yang seorang lagi mengingatkannya. Dan janganlah saksi-saksi itu menolak apabila dipanggil. Dan janganlah kamu bosan menuliskannya, untuk batas waktunya baik (utang itu) kecil maupun besar. Yang demikian itu, lebih adil di sisi Allah, lebih dapat menguatkan kesaksian, dan lebih mendekatkan kamu kepada ketidakraguan, kecuali jika hal itu merupakankan kan perdagangan tunai yang kamu jalankan diantara kamu, tidak maka tidak ada dosa bagi kamu jika kamu tidak menuliskannya. Dan ambillah saksi apabila kamu berjual beli, dan janganlah kamu penulis dipersulit dan begitu juga saksi. Jika kamu lakukan ( yang demikian), maka sungguh, suatu kefasikan pada kamu. Dan bertakwalah kepada Allah, Allah memberikan pengajaran kepadamu, dan Allah Maha Mengetahui segala sesuatu. ${ }^{21}$

Ayat ini adalah yang terpanjang dalam Alquran, dan dengan jelas memuat petunjuk pencatatan transaksi ekonomi.Paragraf ini merupakan paragraf paling jelas yang membahas tentang konvensi akuntansi.Ada 8 kata dalam kata record pada paragraf ini, dan catatan merupakan bagian dari fungsi utama akuntansi.Paragraf ini menjelaskan fungsi

\footnotetext{
${ }^{21} \mathrm{Al}-\mathrm{Mujib}$, Al-Qur'an Dan Terjemahannya.
} 
pencatatan transaksi, dasar dan manfaat transaksi, sebagaimana dijelaskan oleh prinsip hukum yang harus diikuti. Seperti yang tertera di awal ayat: "Hai, orang-orang yang beriman apabila kamu bermuamalah tidak secara tunai secara tunai untuk waktu yang ditentukan, hendaklah kamu menuliskannya. Dan hendaklah seorang penulis di antara kamu menuliskannya dengan benar. Dan janganlah penulis enggan menuliskannya sebagaimana Allah telah mengajarkannya"

3. Evaluasi (Auditing)

Auditing adalah dalah proses pengumpulan dan evaluasi bukti informasi terukur terkait entitas ekonomi, proses ini dilakukan oleh personel yang kompeten dan independen sehingga dapat melaporkan kesesuaian informasi yang dikutip dengan standar yang telah ditetapkan. ${ }^{22}$ Sedangkan menurut Mulyasa dalam evaluasi keuangan sekolah, pengawasan merupakan salah satu proses yang harus dilakukan dalam manajemen pembiayaan berbasis sekolah. Dalam pengelolaan keuangan sekolah, kepala sekolah perlu mengontrol pengeluaran keuangan sekolah sesuai dengan anggaran yang telah ditetapkan. ${ }^{23}$ Menurut Nanang Fattah, sederhananya, proses pemantauan meliputi tiga kegiatan, yakni pemantauan, evaluasi, dan pelaporan. ${ }^{24}$

Proses evaluasi ini dilakukan agar kegiatan yang terkait dengan pengelolaan keuangan dapat berjalan dengan efektif, dan tidak ada penyimpangan dalam prosesnya. Di sinilah kepala sekolah harus memantau dan mengevaluasi hasilnya. Ada beberapa jenis-jenis Auditing :

a. Audit Laporan Keuangan, Audit laporan keuangan bertujuan menentukan apakah laporan keuangan secara keseluruhan yang merupakan informasi terukur yang akan diverifikasi,telah disajikan sesuai dengan kriteria-kriteria tertentu.

b. Audit Operasional, Audit operasional adalah evaluasi atas setiap bagian dari prosedur dan metode operasional organisasi untuk menilai efisiensi dan efektivitasnya. Biasanya, setelah menyelesaikan audit operasi, auditor akan memberikan banyak saran kepada manajemen untuk meningkatkan proses operasi organisasi.

\footnotetext{
${ }^{22}$ Tim Dosen Administrasi Pendidikan UPI, Manajemen Pendidikan (Bandung: Alfabeta, 2009).

${ }^{23}$ E. Mulyasa, Manajemen Berbasis Sekolah (Bandung: PT Remaja Rosdakarya, 2007).

${ }^{24}$ Nanang Fatah, Ekonomi Dan Pembiayaan (Bandung: Remaja Rosdakarya, 2000).
} 
c. Audit Ketaatan, Audit ketaatan bertujuan ntuk mempertimbangkan apakah auditi (klien) telah mengikuti prosedur atau aturan tertentu yang ditetapkan oleh pihak dengan otoritas yang lebih tinggi. Kajian kepatuhan organisasi swasta (perusahaan) dapat mencakup penentuan apakah pejabat akuntansi telah mengikuti prosedur yang ditetapkan oleh organisasi tersebut.Contoh meninjau gaji, memeriksa perjanjian dengan pihak lain (misalnya bank / kreditor) dan mematuhi persyaratan hukum yang berlaku.

Al-Qur'an menjelaskan bahwa pengaudit harus mengevaluasi secara adil, jangan dilebihkan dan jangan dikurangi. Dalam hal ini, Al-Qur'an menyatakan bahwa:

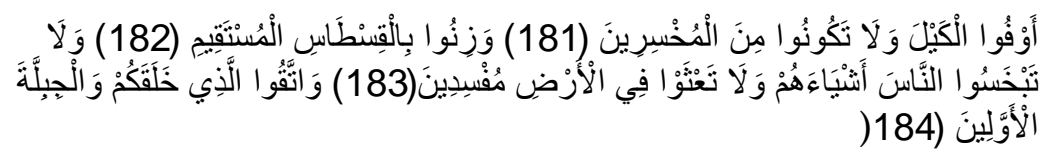

Artinya: "Sempurnakanlah takaran dan janganlah kamu termasuk orang-orang yang merugikan dan timbanglah dengan timbangan yang lurus. Dan janganlah kamu merugikan manusia pada hak-haknya dan janganlah kamu merajalela di muka bumi dengan membuat kerusakan dan bertakwalah kepada Allah yang telah Menciptakan kamu dan umt-umat yang dahulu". (QS. Asy-Syu'ara (26): 181-184). ${ }^{25}$

Kebenaran dan keadilan dalam mengukur datang kepadamu orang fasik membawa suatu berita, maka periksalah dengan teliti,agar kamu tidak menimpakan suatu musibah kepada suatu kaum tanpa mengetahui keadaannya yang menyebabkan kamu menyesal atas perbuatan itu.

Kemudian, sesuai dengan perintah Allah dalam Alquran, kita harus menyempurnakan pengukuran di atas dalam bentuk pos-pos yang disajikan dalam Neraca, sebagaimana digambarkan dalam Surah Al-Israa' ayat 35 yang berbunyi: "Dan sempurnakanlah takaran apabila kamu menakar, dan timbanglah dengan neraca yang benar. Itulah yang lebih utama akibatnya." Dari uraian di atas dapat disimpulkan bahwa prinsip akuntansi dalam konsep hukum Syariah dapat diartikan sebagai kumpulan dari landasan hukum yang baku dan tetap, yang disimpulkan dari sumber-sumber hukum Syariah dan digunakan oleh akuntansi dalam menjalankan fungsinya. Ini

${ }^{25}$ Al-Mujib, Al-Qur'an Dan Terjemahannya. 
digunakan sebagai aturan dalam akuntansi, analisis, pengukuran, eksposur dan interpretasi, dan menjadi dasar untuk menafsirkan peristiwa atau peristiwa.

Adapun etika yang harus dimiliki auditor atau orang yang mengevaluasi keuangan sekolah/madrasah diantaranya:

a. Integritas: Islam menempatkan integritas sebagai nilai tertinggi yang memandu seluruh perilakunya. Islam juga menilai perlunya kemampuan, kompetensi dan kualifikasi tertentu untuk melaksanakan suatu kewajiban;

b. Keikhlasan: Landasan ini berarti bahwa akuntan harus mencari keridhaan Allah dalam melaksanakan pekerjaannya bukan mencari nama, pura-pura, hipokrit dan sebagai bentuk kepalsuan lainnya. Menjadi ikhlas berarti akuntan tidak perlu tunduk pada pengaruh atau tekanan luar tetapi harus berdasarkan komitmen agama, ibadah dalam melaksanakan fungsi profesinya. Tugas profesi harus bisa dikonversi menjadi tugas ibadah;

c. Ketakwaan: Takwa merupakan sikap ketakutan kepada Allah baik dalam keadaan tersembunyi maupun terangterangan sebagai salah satu cara untuk melindungi seseorang dari akibat negatif dari perilaku yang bertentangan dari syari'ah khususnya dlam hal yang berkitan dengan perilaku terhadap penggunaan kekayan atau transaksi yang cenderung pada kezaliman dan dalam hal yang tidak sesuai dengan syari'ah;

d. Kebenaran dan Bekerja Secara Sempurna : Akuntan tidak harus membatasi dirinya hanya melakukan pekerjaanpekerjaan profesi dan jabatannya tetapi juga harus berjuang untuk mencari dan menegakkan kebenaran dan kesempurnaan tugas profesinya dengan melaksanakan semua tugas yang dibebankan kepadanya dengan sebaikbaik dan sesempurna mungkin. Hal ini tidak akan bisa direalisir terkecuali melalui kualifikasi akademik, pengalaman praktik, dan pemahaman serta pengalaman keagamaan yang diramu dalam pelaksanaan tugas profesinya. Hal ini ditegaskan dalam firman Allah dalam Surat An Nahl ayat 9o : Sesungguhnya Allah menyuruh berbuat adil dan berbuat kebajikan, dan dalam Surat Al Baqarah ayat 195: Dan berbuat baiklah, karena sesungguhnya Allah menyukai orang-orang yang berbuat baik.

e. Takut kepada Allah dalam setiap Hal: Seorang muslim meyakini bahwa Allah selalu melihat dan menyaksikan 
semua tingkah laku hambaNya dan selalu menyadari dan mempertimbangkan setiap tingkah laku yang tidak disukai Allah. Ini berarti sorang akuntan/auditor harus berperilaku takut kepada Allah tanpa harus menunggu dan mempertimbangkan apakah orang lain atau atasannya setuju atau menyukainnya. Sikap ini merupakan sensor diri sehingga ia mampu bertahan terus menerus dari godaan yang berasal dari pekerjaan profesinya. Sikap ini ditegaskan dalam firman Allah Surat An Nisa ayat 1 : Sesungguhnya Allah selalu menjaga dan mengawasi kamu. Dan dalam Surat Ar Rad Ayat 33 Allah berfirman : Maka apakah Tuhan yang menjaga setiap diri terhadap apa yang diperbuatnya Allah dalam Surat Thaha ayat 7: Sesungguhnya dia mengetahui rahasia dan apa yang lebih tersembunyi.

f. Manusia bertanggungjawab dihadapan Allah : Akuntan Muslim harus meyakini bahwa Allah selalu mengamati semua perilakunya dan dia akan mempertanggungjawabkan semua tingkah lakunya kepada Allah nanti di hari akhirat baik tingkah laku yang kecil amupun yang besar. Sebagaimana firman Allah dalam Surat Al Zalzalah ayat 7-8 : Barang siapa yang mengerjakan kebaikan seberat zarrah niscaya dia akan melihat (balasan) nya. Dan barang siapa yang mengerjakan kejahatan seberat zarrahpun niscaya dia akan melihat balasnya pula.

Oleh karena itu akuntan/auditor harus selalu ingat bahwa dia akan mempertanggungjawabkan semua pekerjaannya dihadapan Allah dan juga kepada publik, profesi, atasan dan dirinya sendiri. Gambaran singkat ini mudah-mudahan menggugah kita bahwa auditing syari'ah sudah mulai berkembang sejalan dengan perkembangan sistem ekonomi Islam.

\section{A. Manajemen Pembiayaan Pendidikan}

Pembiayaan pendidikan dapat diartikan sebagai ongkos yang harus tersedia dan diperlukan dalam mencapai visi, misi tujuan sasaran, dan strateginya.Pembiayaan terebut diperlukan untuk pengadaan gedung infrastruktur dan peralatan belajar mengajar, gaji guru, gaji karyawan dan sebagainya. ${ }^{26}$

Menurut Nanang Fattah Biaya dalam pendidikan meliputi biaya langsung dan biaya tak langsung.Biaya langsung terdiri dari

\footnotetext{
${ }^{26}$ Abuddin Nata, Ilmu Pendidikan Islam (Bandung: Pernada Media, 2016).
} 
biaya-biaya yang dikeluarkan untuk keperluan pelaksanaan pengajaran dan kegiatan belajar siswa berupa pembelian alat-alat belajar, biaya transportasi, gaji guru, baik yang dikeluarkan oleh pemerintah, orang tua maupun siswa itu sendiri.Sedangkan biaya tidak langsung adalah berupa keuntungan yang hilang. ${ }^{27}$

Pengertian manajemen keuangan ini dijelaskan dalam AlQur'an Surat Al-Mujadilah (58): 12-13 yang berbunyi:

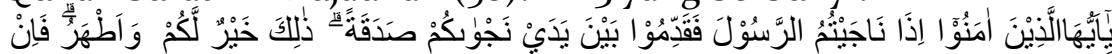

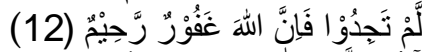

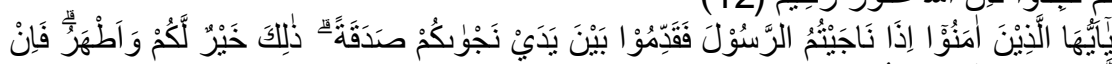

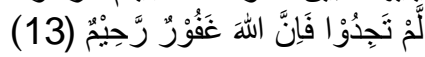
Artinya: Wahai orang-orang yang beriman! Apabila kamu mengadakan pembicaraan khusus dengan Rasul, hendaklah kamu mengeluarkan sedekah (kepada orang miskin) sebelum (melakukan) pembicaraan itu.Yang demikian itu lebih baik bagimu dan lebih bersih. Tetapi jika kamu tidak memperoleh (yang akan disedekahkan) maka sungguh, Allah Maha Pengampun, Maha Penyayang. Apakah kamu takut akan (menjadi miskin) karena kamu memberikan sedekah sebelum (melakukan) pembicaraan dengan Rasul? Tetapi jika kamu tidak melakukannya dan Allah telah memberi ampun kepadamu, maka laksanakanlah salat, dan tunaikanlah zakat serta taatlah kepada Allah dan RasulNya! Dan Allah Mahateliti terhadap apa yang kamu kerjakan. ${ }^{28}$

Surat al-Mujadilah ayat 12-13 di atas memberikan gambaran tentang konsep pembiayaan pendidikan dalam Islam. Ayat 12 memberikan pelajaran bahwa pendidikan itu tidak gratis; bahkan dalam satu riwayat berkaitan dengan turunnya ayat ini menjelaskan bahwa bahwa pendidikan itu jangan terlalu murah. Dalam ayat ini Allah Swt. memberikan persyaratan kepada kaum muslimin yang hendak bertanya (belajar) kepada Rasulullah saw. untuk mengeluarkan sedekah kepada fakir miskin. Mengeluarkan sedekah dalam ayat ini bisa kita asumsikan sebagai biaya pendidikan yang harus dikeluarkan oleh si pencari ilmu.

Syarat mengeluarkan sedekah dalam ayat ini mempunyai tujuan, yaitu untuk mencegah kaum muslimin bertanya secara berlebihan atau terlalu sering bertanya sehingga hal ini membebani Rasulullah saw. Dengan adanya syarat tersebut, maka kaum muslimin berpikir dua kali untuk lebih sering bertanya kepada Rasulullah saw. Dalam realita dunia pendidikan yang terjadi, biaya pendidikan yang dibebankan kepada peserta didik

\footnotetext{
${ }^{27}$ Ahmad Munir, "Manajemen Pembiayaan Pendidikan Dalam Perspektif Islam," Jurnal AtTa'dib 8, no. 2 (2013): 225.

${ }^{28} \mathrm{Al}-\mathrm{Mujib}$, Al-Qur'an Dan Terjemahannya.
} 
juga mempunyai tujuan, walaupun tidak persis sama dengan tujuan yang tertera dalam surat al Mujadilah ayat 12. Tujuan yang paling utama dari biaya pendidikan yang harus ditanggung oleh peserta didik adalah untuk menunjang kelancaran berlangsungnya proses belajar mengajar. Di samping itu, dana pendidikan yang dibebankan kepada para peserta didik bertujuan untuk mengikat para peserta didik agar mereka belajar secara sungguh-sungguh, dengan asumsi bahwa mereka akan merasa rugi kalau tidak belajar dengan sungguh-sungguh setelah mereka mengeluarkan biaya yang harus mereka bayar.

Selanjutnya ayat 13 dalam surat Al-Mujadalah ini memberikan pelajaran khususnya bagi mereka yang memangku tanggung jawab dalam pengelolaan pendidikan. Dalam ayat ini Allah Swt. memberikan keringanan kepada kaum muslimin yang ingin bertanya (belajar) kepada Rasulullah saw. tapi mereka tidak mampu untuk memberi sedekah kepada fakir miskin, maka Allah memberikna keringanan berupa penggantian kewajiban dengan mendirikan shalat, atau membayar zakat dan ta'at kepada Allah dan rasul-Nya.

Dewasa ini, dunia pendidikan secara umum telah memberlakukan biaya pendidikan berupa sejumlah uang. Bahkan dalam beberapa kasus, banyak lembaga pendidikan (sekolah) yang tidak menerima calon siswa tidak mampu membayar biaya pendidikan (padahal secara intelektual mereka mampu), ataupun kasus yang lain adalah beberapa sekolah mengeluarkan siswanya hanya karena mereka tidak mampu mebayar SPP atau membayar uang ujian. Kalau berkaca dari ayat 13 di atas, memberikan gambaran bahwa ketika seorang siswa tidak mampu untuk membayar biaya pendidikan, maka mereka berhak untuk membayar dengan bentuk yang lain. Bisa berupa bentuk materi ataupun jasa yang lain; seperti: membayar dengan hasil pertanian, hasil ladang, ataupun berupa jasa. Bila kita mencoba untuk kembali ke dalam sejarah perjalanan pendidikan di Indonesia, maka konsep yang diajarkan dalam surat al-Mujadilah ayat 12 dan 13 ini telah diterapkan oleh lembaga pendidikan Pesantren Tradisional. Para santri yang menuntut ilmu kepada kyainya tidak dibebankan untuk membayar dengan berupa jumlah uang; tapi mereka ada yang membawa hasil pertanian-berupa padi, ataupun ada yang membawa hasil perladangan, seperti ketela, pisang ataupun yang lainnya, atau bahkan ada di antara mereka yang hanya membawa kayu bakar.

Selanjutnya, di pesantren tradisional pun tidak mempersalahkan santri yang tidak mampu membayar berupa 
materi ataupun barang, tapi mereka diberdayakan oleh para kyai untuk membantu mengurus kekayaan kyai, seperti memelihara kolam, mencangkul di sawah, ataupun bekerja di kebun atau ladang. Hal ini menunjukkkan bagaimana para kyai yang mengajar di pesantren tradisional menerapkan prinsip pembiayaan sebagaimana yang tercantum dalam surat alMujadilah ayat 12 dan 13.

\section{B. Sumber-Sumber Pembiayaan Pendidikan Islam}

Dalam hal menghimpun dana (raising funds) pada dasarnya dapat digali dari dua sumber, yaitu berasal dari dalam lembaga sendiri (intern) dan melalui pihak luar (ekstern). Yaitu:

1. Pemerintah dan masyarakat

2. Dalam Undang-Undang Sistem Pendidikan nomor 20 tahun 2003 pasal 46 ayat 1 dijelaskan bahwa pendanaan pendidikan menjadi tanggung jawab bersama antara Pemerintah, pemerintah daerah, dan masyarakat. Dalam pasal 49 ayat 3 juga dijelaskan bahwa dana dari pemerintah tersebut berbentuk hibah untuk satuan pendidikan. Berdasarkan Undang-undang diatas, jelaslah bahwa sumber utama bagi pendanaan pendidikan berasal dari pemerintah yang di dukung oleh masyarakat.

3. Wakaf

Wakaf adalah sumbangan dalam pengertian umum merupakan hadiah yang diberikan untuk memenuhi banyak kebutuhan spiritual dan temporal kaum muslimin.Dana-dana yang diperoleh dari sumbangan tersebut digunakan untuk membangun dan merawat tempat ibadah, mendirikan sekolah dan rumah sakit, menafkahi para ulama dan da'i, mempersiapkan kebutuhan kaum muslimin dan memasok senjata bagi para pejuang yang berperang di jalan Allah. ${ }^{29}$ Salah satu sumber dana bagi pendidikan islam ialah wakaf dari orang islam. Wakaf berasal dari amal dengan cara memanfaatkan harta, dan harta itu harus dikekalkan, atau yang digunakan adalah hasil harta itu, tetapi asalnya tetap. Dengan melihat definisi ini saja kita sudah menangkap bahwa biaya pendidikan yang berasal dari wakaf pasti amat baik karena biaya itu terus menerus dan modalnya tetap.Ini jauh lebih baik dari pada pemberian uang atau bahan yang habis sekali pakai. Sebagaimana firman Allah dalam Alquran Surat Al-Baqarah (2): 195 yang artinya: Dan belanjakanlah (harta

${ }^{29}$ Ramayulis, Manajemen Pendidikan Islam (Jakarta: kalam Mulia, 2008). 
bendamu) di jalan Allah, dan janganlah kamu menjatuhkan dirimu sendiri ke dalam kebinasaan, dan berbuat baiklah, karena sesungguhnya Allah menyukai orang-orang yang berbuat baik. ${ }^{30}$

4. Zakat

Pendidikan termasuk ke dalam kepentingan sosial, sudah sepantasnya zakat dapat dijadikan sumber dana pendidikan. Dana zakat harus dikelola secara profesional dan transparan agar sebagiannya dapat dipergunakan untuk membiayai lembaga pendidikan Islam.

Zakat merupakan salah satu dari rukun Islam yang lima, dan disebut beriringan dengan shalat pada 82 ayat. Dan Allah telah menetapkan hukum wajibnya, baik dengan kitab-Nya maupun dengan Sunnah Rasul-Nya serta Ijma' dari umatnya. Dalam Alquran surat At-Taubah (10) ayat 103:

Artirnya : Pungutlah zakat dari sebagian harta mereka, dengan zakat itu kamu membersihkan dan menyucikan mereka, dan mendoalah untuk mereka. Sesungguhnya doa kamu itu (menjadi) ketentraman jiwa bagi mereka. Dan Allah Maha Mendengar lagi Maha Mengetahui. ${ }^{31}$

Ayat ini menjelaskan bahwa ambillah zakat hai Rasul, dari harta kekayaan orang-orang mukmin itu baik yang tertentu sebagai kewajiban, maupun yang tidak tertentu sebagai tathawwu' (sukerela) guna membersihkan mereka dari penyakit kikir dan serakah, sifat-sifat rendah dan kejam terhadap fakir miskin dan orang-orang yang tidak punya dan sifat-sifat hina lainnva. Juga untuk menyucikan jiwa mereka, menumbuhkan dan mengangkat derajatnya dengan berkah dan kebajikan, baik dari segi moral maupun amal, hingga dengan demikian ia akan layak mendapatkan kebahagiaan, baik di dunia maupun akhirat.

Dengan demikian dapat kita simpulkan bahwa dalam masyarakat kaum muslimin, mereka mempunyai sumber pembiayaan pendidikan potensial yang apabila masyarakat bisa memahaminya dan dimotivasi untuk berperan serta aktif mengeluarkannya, sungguh ini merupakan sumber biaya yang cukup besar bagi pendidikan khususnya lembaga pendidikan Islam.

\footnotetext{
${ }^{30}$ Al-Mujib, Al-Qur'an Dan Terjemahannya.

${ }^{31} \mathrm{Al}-\mathrm{Mujib}$.
} 


\section{Tujuan dan Fungsi Manajemen Keuangan dan Pembiayaan Pendidikan}

Adapun tujuan dari manajemen keuangan dan pembiayaan adalah untuk memperoleh, dan mencari peluang sumber-sumber pendanaan bagi kegiatan sekolah, agar bisa menggunakan dana secara efektif dan tidak melanggar aturan, dan membuat laporan keuangan yang transparan dan akuntabel. Di sinilah peran seorang manager sekolah atau Kepala Sekolah untuk mengelola keuangan dengan sebaik mungkin dengan memperdayakan sumber daya manusia yang ada di lingkungan sekolah melalui kegiatan manajemen keuangan maka kebutuhan pendanaan kegiatan sekolah dapat direncanakan, diupayakan pengadaannya, dibukukan secara transparan, dan digunakan untuk membiayai pelaksanaan program sekolah secara efektif dan efisien. Untuk itu tujuan manajemen keuangan adalah:

1. Meningkatkan efektivitas dan efisiensi penggunaan keuangan sekolah

2. Meningkatkan akuntabilitas dan transparansi keuangan sekolah. ${ }^{32}$

3. Meminimalkan penyalahgunaan anggaran sekolah.

Untuk mencapai tujuan tersebut, maka dibutuhkan kreativitas kepala sekolah dalam menggali sumber-sumber dana, menempatkan bendaharawan yang menguasai dalam pembukuan dan pertanggung-jawaban keuangan serta memanfaatkannya secara benar sesuai peraturan perundangan yang berlaku.n Selanjutnya fungsi manajemen keuangan dalam pendidikan adalah untuk melaksanakan kegiatan agar suatu tujuan tercapai dengan efektif dan efisien. Secara tegas tidak ada rumusan yang sama dan berlaku umum untuk fungsi manajemen..$^{33}$

Supervisi sebagai pelayanan yang disediakan oleh pemimpin untuk membawa guru (orang yang dipimpin) agar menjadi guru atau personil yang

\footnotetext{
${ }^{32}$ Kadarman Jusuf, Pengantar IImu Manajemen (Jakarta: PT. Gramedia Pustaka Utama, 2016).

${ }^{33}$ Hidayat and Wijaya, Ayat-Ayat Al-Qur'an Tentang Manjemen Pendidikan Islam.
} 
semakin cakap sesuai dengan perkembangan ilmu pengetahuan pada umumnya dan ilmu pendidikan khususnya agar dapat meningkatkan efektivitas proses pembelajaran di Madrasah. Supervisi adalah kegiatan yang dilakukan oleh pengawas satuan pendidikan dalam rangka membantu Kepala Madrasah, guru dan tenaga kependidikan lainnya gunameningkatkan mutu dan efektivitas penyelenggaraan pendidikan dan pembelajaran.

Menurut Sahertian, supervisi adalah usaha memberi layanan kepada guru-guru baik secara individual maupun secara kelompok dalam usaha memperbaiki pengajaran. ${ }^{34}$ Supervisi pada dasarnya diarahkan pada dua aspek, yakni: supervisi akademis, dan supervisi manajerial. Supervisi akademis menitikberatkan pada pengamatan supervisor terhadap kegiatan akademis, berupa pembelajaran baik di dalam maupun di luar kelas. Supervisi manajerial menitik beratkan pada pengamatan pada aspek- aspek pengelolaan dan administrasi sekolah yang berfungsi sebagai pendukung (supporting) terlaksananya pembelajaran. ${ }^{35}$

Supervisi akademik merupakan kegiatan yang ditujukan untuk memperbaiki dan meningkatkan mutu proses dan hasil pembelajaran. Tentunya, melibatkan seluruh pihak yang terkait dalam proses pembelajaran. Dalam praktek supervisi akademik, antara Kepala Madrasah dan guru tidak diberlakukan sebagai atasan dan bawahan, melainkan sebagai teman sejawat. Tata kerja yang dikembangkan adalah bekerja bersama (work with), kendatipun struktur organisasi yang birokratik tetap dihargai. Karena pendekatan perilaku supervisi adalah menciptakan dan menjaga keselarasan antara kepentingan pribadi (personal needs) dan tujuan-tujuan organisasi (institutional goals) melalui kerja tim evaluasi terhadap sasaran-sasaran supervisi. ${ }^{36}$

Dengan demikian supervisi menekankan kepada pemberian bantuan, pelayanan atau jasa kepada guru dengan maksud untuk meningkatkan kemampuan yang dimiliki oleh guru sehingga dengan begitu terwujudlah profesionalisme guru yang akan membawa pada motivasi belajar siswa yang tinggi.

Sementara Arikunto menekankan kegiatan supervisi akademik sebagai kegiatan yang fokus pada permasalah akademik guru. Supervisi akademik adalah supervisi yang menitikberatkan pada permasalahan akademik yang berkaitan langsung pada proses belajar mengajar atau kegiatan

\footnotetext{
${ }^{34}$ Piet A. Sahertian, Konsep Dasar dan Teknik Supervisi Pendidikan Dalam Rangka Pengembangan Sumber Daya Manusia (Jakarta: PT. Rineka Cipta, 2008), 19.

${ }^{35}$ Direktorat Tenaga Kependidikan Direktorat Jenderal Peningkatan Mutu Pendidik Dan Tenaga Kependidikan Departemen Pendidikan Nasional. Metode Dan Teknik Supervisi (Jakarta: Ditjen PMPTK, 2008), 6.

${ }^{36}$ Tim Penyusun, Standar Supervisi E Evaluasi Pendidikan (Supervisi Akademik dan Evaluasi Program) (Jakarta: Depag RI, 2003), 6.
} 
pembelajaran. ${ }^{37}$ Sedangkan menurut Daresh yang senada dengan pendapat Glickman sebagaimana dikutib Rodliyah menjelaskan lebih luas bahwasanya supervisi akademik adalah serangkaian kegiatan membantu guru mengembangkan kemampuannya mengelola proses pembelajaran untuk mencapai tujuan pembelajaran. ${ }^{38}$ Dengan demikian, proses supervisi sangat berkaitan dengan upaya dalam peningkatan kualitas para guru dalam pelaksanaan pembelajaran.

Kepala Madrasah menempati posisi yang strategis dalam rangka melaksanakan tugasnya sebagai supervisor, karena setiap hari ia dapat langsung melihat dan menyaksikan kejadian, bahkan dengan langsung pula dapat memberikan pembinaan untuk peningkatan. Dengan kedudukannya ini, maka Kepala Madrasah merupakan supervisor yang sangat tepat, karena kepala madrasahlah yang paling memahami seluk-beluk dan kondisi madrasah. ${ }^{39}$

Kompetensi supervisi akademik intinya adalah membina guru dalam meningkatkan mutu proses pembelajaran. Sasaran supervisi akademik adalah guru dalam melaksanakan proses pembelajaran, yang terdiri dari materi pokok dalam proses pembelajaran, penyusunan silabus dan RPP, pemilihan strategi/metode/teknik pembelajaran, penggunaan media dan teknologi informasi dalam pembelajaran, menilai proses dan hasil pembelajaran serta penelitian tindakan kelas. Oleh karena itu, kepala madrasah sebagai supervisor dituntut menguasai strategi/teknik pembinaan guru agar dapat menerapkan kompetensi supervisi akademik secara efektif, yaitu: a) Memahami konsep, prinsip, teori dasar, karakteristik, dan kecenderungan perkembangan setiap mata pelajaran, b) Memahami konsep, prinsip, teori/teknologi, karakteristik, dan kecenderungan perkembangan proses pembelajaran/bimbingan, c) Membimbing guru dalam menyusun silabus yang berlandaskan standar isi, standar kompetensi dan kompetensi dasar, dan prinsipprinsip pengembangan KTSP, d) Membimbing guru dalam memilih dan menggunakan strategi/metode pembelajaran/bimbingan yang dapat mengembangkan berbagai potensi siswa, e) Membimbing guru dalam menyusun rencana pelaksanaan pembelajaran (RPP), f) Membimbing guru dalam melaksanakan kegiatan pembelajaran/bimbingan (di kelas, laboratorium, dan lapangan), g) Membimbing guru dalam mengelola, merawat, mengembangkan dan menggunakan media pendidikan dan fasilitas

${ }^{37}$ Suharsimi Arikunto, Dasar-Dasar Supervisi (Jakarta: PT. Rineka Cipta, 2006), 5 .

${ }^{38}$ St. Rodliyah, Supervisi Pendidikan dan Pembelajaran (Jember: STAIN Jember Press, 2014), 136.

${ }^{39}$ Suharsimi Arikunto, Dasar-Dasar Supervisi, 75. 
pembelajaran/ bimbingan, h) Memotivasi guru untuk memanfaatkan teknologi informasi dalam. pembelajaran/bimbingan..$^{0}$

Supervisi merupakan kegiatan pertolongan yang berlangsung terusmenerus dan sistematis yang diberikan kepada guru-guru agar mereka semakin bertumbuh dan berkembang dalam meningkatkan kualitas proses pembelajaran sehingga berkaitan dengan peningkatan profesionalitas guru. Dapat dijabarkan dalam gambar berikut ini keterkaitan antara pelaksanaan supervisi akademik kepala madrasah dengan meningkatkan profesionalisme guru dan motivasi belajar siswa.

keterkaitan antara pelaksanaan supervisi akademik, guru profesional dan motivasi belajar siswa

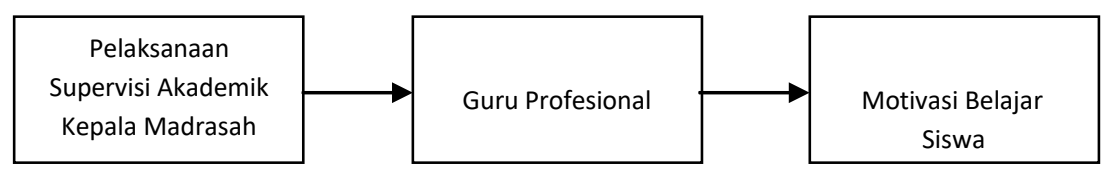

Logika dari adanya pelaksanaan supervisi akademik oleh kepala madrasah maka akan mampu meningkatkan profesionalisme guru sehingga pada akhirnya bisa memacu motivasi belajar siswa, dan dari motivasi belajar yang kuat ini diharapkan bisa mencapai tujuan dari pendidikan itu sendiri.

\section{Pelaksanaan supervisi akademik kepala madrasah dalam membantu guru menyusun rencana pembelajaran}

Kepala Madrasah yang merupakan pemimpin dalam sebuah lembaga pendidikan mempunyai tugas untuk melaksanakan supervisi akademik. Salah satu tugas Kepala Madrasah dalam supervisi akademik adalah membantu guru menyusun rencana pembelajaran. Rencana pembelajaran dibutuhkan sebagai acuan pelaksanaan pembelajaran. Dalam beberapa hasil wawancara dengan Kepala Madrasah dan para guru terkumpul informasi terkait pelaksanaan supervisi akademik dalam membantu guru menyusun rencana pembelajaran.

Data hasil wawancara dengan Kepala Madrasah, Imam Sauqi menjelaskan bahwasanya;

"Program supervisi diawali dengan memeriksa kelengkapan perangkat pembelajaran yang telah dipersiapkan dan akan digunakan oleh guru dalam proses pembelajaran. Pemeriksaan administrasi kelengkapan perangkat pembelajaran dilakukan dalam satu kali pertemuan. Setelah melakukan pemeriksaaan terhadap perangkat pembelajaran guru, selanjutnya akan memberitahu guru mengenai perangkat apa yang

${ }^{40}$ Abd. Kadim Masaong, Supervisi Pembelajaran dan Pengembangan Kapasitas GuruMemberdayakan Pengawas sebagai Gurunya Guru (Bandung: CV.Alfabeta, 2003), 72. 
kurang dan harus dilengkapi oleh guru yang bersangkutan. Dalam kurun waktu yang telah disepakati, biasanya dalam satu bulan, guru kelas telah melengkapi perangkat yang belum lengkap atau sempurna. Setelah guru melengkapi perangkat utama pembelajaran, barulah dilakukan supervisi akademik yang biasanya berbentuk kunjungan kelas untuk menilai performa guru dalam proses pembelajaran". ${ }^{41}$

Hal serupa juga disampaikan oleh Moh. Hasan Basri selaku waka kurikulum yang menegaskan bahwasanya;

"disini rencana pembelajaran itu hukumnya wajib bagi semua guru, tidak ada alasan bagi guru-guru untuk tidak membuat rencana pembelajaran karena semua itu sudah ada jadwal yang telah ditentukan atau disepakati untuk mengkonsultasikan semua rencana pembelajar mulai dari kalender, silabus hingga RPP dll yaitu sebelum tahun ajaran baru dan kepala madrasah selalu mengatakan disetiap kesempatan bahwa siap dan bersedia membantu guru dalam menyusun rencana pembelajaran". ${ }^{42}$

Hal ini dilakukan sebagai salah satu upaya Kepala Madrasah dalam meningkatkan profesionalisme guru untuk menjadikan peserta didiknya selalu termotivasi untuk belajar. Sebagaimana dibenarkan oleh salah satu guru pengampu mata pelajaran SKI yakni Eftihori, yang mengatakan bahwasanya;

"Rencana pelaksanaan pembelajaran di Madrasah Tsanawiyah Muqoddimatul Akhlak merupakan suatu keharusan yang selalu diperiksa pada setiap akhir tahun pelajaran kita sebagai tenaga pendidik menyiapkan rencana pembelajaran untuk proses pembelajaran selama satu tahun ke depan dan diperlihatkan kepada Kepala Madrasah sebelum tahun ajaran baru dimulai jadi segala sesuatu yang berkenaan dengan proses pembelajaran kita selesaikan sebelum tahun ajaran baru dimulai, mulai dari kalender pendidikan, program tahunan, program semester, kemudian silabus kita garap sampai pada RPPnya. Yang penting kita garap dulu, kalaupun ternyata nanti setelah diperiksa oleh Kepala Madrasah masih ada kekurangan yang perlu diperbaiki, ya kita perbaiki lagi sesuai dengan apa yang diarahan oleh Kepala Madrasah". ${ }^{43}$

Pentingnya pelaksanaan supervisi akademik adalah untuk meningkatkan kemampuan profesional guru dan meningkatkan kualitas pembelajaran melalui proses pembelajaran yang baik serta membantu guru dan Kepala Madrasah menciptakan lulusan yang baik dari segi kualitas maupun kuantitas.

\footnotetext{
${ }^{41}$ Imam Sauqi, Wawancara, Silo, 1 April 2015

${ }^{42}$ Moh. Hasan Basri, Wawancara, Silo, 1 April 2015.

${ }^{43}$ Eftihori, Wawancara, Silo, 1 April 2015
} 
Oleh karena itu, kegiatan supervisi ini hendaknya rutin dilaksanakan di Madrasah sebagai salah satu kegiatan yang dipandang positif dalam meningkatkan proses pembelajaran. Apabila konsep-konsep ideal tersebut dilaksanakan, maka dapat diharapkan kualitas pendidikan akan meningkat secara signifikan. Dari sini dapat dipaparkan hasil temuan pada fokus satu.

Temuan penelitian pada fokus ini yaitu: pertama, Semua guru diwajibkan membuat Rencana pembelajaran (RPP). Kedua, semua guru diberikan kesempatan untuk melakukan konsultasi dan bimbingan kepada kepala madrasah mengenai rencana pembelajaran. Ketiga, kegiatan supervisi telah terjadwal dalam rencana program supervisi kepala madrasah dengan teknik pertemuan individu, dengan proses awal memeriksa RPP guru yang akan disupervisi, memberikan penilaian terhadap RPP dan memberikan saran revisi jika diperlukan untuk perbaikan perangkat pembelajaran selanjutnya. Temuan penelitian diformulasikan dalam bentuk tabel, sebagai berikut:

Tabel 1: Temuan Penelitian

\begin{tabular}{|c|c|}
\hline Fokus 1 & Temuan Penelitian \\
\hline \multirow{3}{*}{$\begin{array}{l}\text { Pelaksanaan supervisi } \\
\text { akademik kepala madrasah } \\
\text { dalam membantu guru } \\
\text { menyusun perangkat } \\
\text { pembelajaran sebagai upaya } \\
\text { meningkatkan } \\
\text { profesionalisme guru untuk } \\
\text { memotivasi belajar siswa }\end{array}$} & $\begin{array}{l}\text { Semua guru diwajibkan membuat } \\
\text { RPP }\end{array}$ \\
\hline & $\begin{array}{l}\text { Semua guru diberikan kesempatan } \\
\text { untuk melakukan konsultasi dan } \\
\text { bimbingan kepada kepala madrasah } \\
\text { mengenai rencana pembelajaran yang } \\
\text { telah dibuat }\end{array}$ \\
\hline & $\begin{array}{l}\text { Kegiatan supervisi telah terjadwal } \\
\text { dalam rencana program supervisi } \\
\text { kepala madrasah dengan teknik } \\
\text { pertemuan individu, dengan proses } \\
\text { awal memeriksa RPP guru yang akan } \\
\text { disupervisi, memberikan penilaian } \\
\text { terhadap RPP dan memberikan saran } \\
\text { revisi jika diperlukan untuk perbaikan } \\
\text { perangkat pembelajaran selanjutnya. }\end{array}$ \\
\hline
\end{tabular}

Keberadaan RPP merupakan standar yang harus dipenuhi oleh setiap guru dalam melaksanakan proses pembelajaran. Sebagaimana dalam 
Peraturan Menteri Pendidikan Nasional Republik Indonesia Nomor 41 tahun 2007 tentang Standar Proses menyatakan bahwa standar proses untuk satuan pendidikan dasar dan menengah mencakup perencanaan proses pembelajaran, pelaksanaan proses pembelajaran, penilaian hasil pembelajaran dan pengawasan proses pembelajaran. ${ }^{44}$

Hal ini juga berimplikasi pada pengembangan kompetensi atau kemampuan seorang guru dalam menyusun RPP yang menjadi acuan dalam pelaksanaan pembelajaran. Pembinaan kemampuan guru sebagai suatu sistem didalamnya terdapat beberapa komponen yang satu sama lainnya mempunyai peran dan jalinan yang erat. Komponen-komponen yang terkait dalam pembinaan kemampuan guru adalah: kepala madrasah, pengawas, serta instasi pendidikan lainnya yang terkait. Supervisor pendidikan yang dalam hal ini adalah kepala madrasah, bertanggungjawab sepenuhnya terhadap pengembangan kompetensi guru dalam proses pembelajaran. Pembinaan hendaknya berfokus pada ketiga aspek kemampuan mengajar guru tersebut, agar proses pembelajaran berlangsung seoptimal mungkin.

Tinggi rendahnya kualitas pembelajaran sangat tergantung pada tinggi rendahnya kompetensi guru dalam mengaplikasikan apa yang telah dirancangnya dalam proses pembelajaran. Oleh karena itu, proses supervisi yang bersifat siklus harus benar-benar diimplementasikan oleh supervisor. Siklus yang dimaksud disiniadalah bahwa kegiatan supervisi untuk tahap pra observasi bertujuan untuk memperoleh gambaran tentang kesiapan guru secara administratif, psikologis dan rancangan pembelajaran. Tahap observasi dilakukan untuk mensinkronkan apakah yang dirancang oleh guru benarbenar dilaksanakan dalam proses pembelajaran serta untuk mengukur tingkat kemampuan guru dalam proses pembelajaran. Sedangkan tahap postconference dilaksanakan untuk saling memberikan umpan balik antara guru dan supervisor. Tahap ini mengakomodasi segala sesuatu yang berkaitan dengan proses pembelajaran serta menyimpulkan dan merekomendasi halhal yang perlu dilaksanakan guru dan supervisor dalam tugas-tugas berikutnya. Di sinilah pentingnya kemitraan dan komunikasi informal dalam menjalankan kegiatan supervisi, serta keterkaitannya dengan pendekatan dan orientasi supervisi yang dianut oleh supervisor sesuai analisis tingkat komitmen dan abstraksi guru.

Kepala Madrasah sebagai supervisor diharapkan mampu melaksanakan tugasnya dengan baik dan memiliki kompetensi supervisi. Kompetensi supervisi yang dimaksudkan adalah kompetensi supervisi akademik.

Kompetensi supervisi akademik intinya adalah membina guru dalam meningkatkan mutu proses pembelajaran. Sasaran supervisi akademik adalah guru dalam melaksanakan proses pembelajaran, yang terdiri dari materi

\footnotetext{
${ }^{44}$ Peraturan Menteri Pendidikan Nasional Republik Indonesia Nomor 41 tahun 2007 tentang Standar Proses
} 
pokok dalam proses pembelajaran, penyusunan silabus dan RPP, pemilihan strategi/metode/teknik pembelajaran, penggunaan media dan teknologi informasi dalam pembelajaran, menilai proses dan hasil pembelajaran serta penelitian tindakan kelas. ${ }^{45}$

Dalam rangka memenuhi tuntutan tersebut di MTs Muqoddimatul Akhlak para guru diwajibkan untuk membuat RPP dan perangkat pembelajaran lainnya. Penyusunan perangkat pembelajaran tersebut tidak lepas dari tugas kepala madrasah sebagai supervisor. Dalam hal ini kepala madrasah senantisa membantu dan membimbing para guru dalam menyelesaikan perangkat pembelajaran yang telah menjadi kewajiban seorang guru yang harus dipenuhi sebelum pembelajaran di kelas terealisasi.

Hal inipun sesuai dengan standar yang ditetapkan dalam SNP, adapun lingkup standar nasional pendidikan meliputi: standar isi, standar proses, standar kompetensi lulusan, standar pendidik dan tenaga kependidikan, standar sarana dan prasarana, standar pengelolaan, standar pembiayaan dan standar penilaian pendidikan. ${ }^{46}$

Standar-standar tersebut merupakan acuan dan kriteria dalam menetapkan keberhasilan penyelenggaraan pendidikan. Standar pendidik dan tenaga kependidikan merupakan salah satu standar yang memegang peranan penting dalam pelaksanaan pendidikan di madrasah. Salah satu komponen penting dalam pelaksanaan pendidikan di madrasah adalah guru, yang merupakan pelaku aktif dalam pembelajaran di kelas.

Guru merupakan ujung tombak dari keberhasilan sebuah pendidikan. Untuk itu guru harus mampu melaksanakan pembelajaran dengan baik, sehingga peserta didikpun dapat mengikuti pembelajaran secara efektif dan efisien serta bermakna. Pembelajaran yang baik akan terealisasi ketika perencaan yang dibuat juga baik. Lebih awal, yang perlu dipersiapkan oleh guru sebelum masuk ke dalam kelas adalah menyiapkan rencana pembelajaran terlebih dahulu.

\section{Pelaksanaan supervisi akademik kepala madrasah dalam membantu mengembangkan kemampuan guru mengelola proses pembelajaran}

Pelaksanaan supervisi akademik yang dilakukan Kepala Madrasah untuk membantu mengembangkan kemampuan guru dalam proses pembelajaran dapat dilakukan dengan baik melalui teknik yang ada. Adapun teknik supervisi akademik ada dua, yaitu teknik supervisi individual seperti; kunjungan kelas, observasi kelas, pertemuan individual, kunjungan antarkelas, dan menilai diri sendiri. Sedangkan teknik supervisi kelompok diantaranya terdiri dari; kepanitiaan-kepanitiaan, kerja kelompok,

\footnotetext{
${ }^{45}$ Lantip Dian Prasojo dan Sudiyono, Supervisi Pendidikan (Yogyakarta: Gava Media, 2011), 83.

${ }^{46}$ Peraturan Pemerintah Nomor 19 Tahun 2005 tentang Standar Pendidikan Nasional
} 
laboratorium dan kurikulum, membaca terpimpin, demonstrasi pembelajaran, darmawisata, kuliah/studi, diskusi panel, perpustakaan, organisasi profesional, buletin supervisi, pertemuan guru, lokakarya atau konferensi kelompok. Sedangkan dalam pelaksanaanya di MTs Muqoddimatul Akhlak ini menggunakan teknik individu dengan cara kunjungan dan observasi kelas, serta membuka kesempatan untuk berdiskusi kepada masing-masing guru untuk konsultasi dalam pertemuan individu. Sebagaimana telah terjadwal dalam dokumen program supervisi Kepala Madrasah.

Imam Sauqi sebagai Kepala Madrasah menjelaskan secara singkat terkait pelaksanaan supervisi akademik dalam membantu guru mengembangkan kemampuan guru mengelola proses pembelajaran, sebagaimana dikutip dari data hasil wawancara sebagai berikut;

"Dari sekian jenis teknik supervisi akademik tersebut, tidak semuanya diterapkan sekaligus. Dan yang sering dilaksanakan di MTs Muqoddimatul Akhlak ini, yaitu; kunjungan kelas, observasi kelas dan pertemuan individu. Kenapa masih itu yang dilaksanakan, ya, karena pada saat ini teknik itulah yang yang lebih tepat untuk diterapkan, dan itu menurut saya pribadi masih efektif. Karena saya dapat menyaksikan sendiri kegiatan proses pembelajar yang berlangsung. Kalau melalui katanya dan katanya, itu bisa saja tidak obyektif". ${ }^{47}$

Untuk mengetahui sejauh mana guru mampu melaksanakan pembelajaran, secara berkala Kepala Madrasah perlu melaksanakan kegiatan supervisi, yang dapat dilakukan melalui kegiatan kunjungan kelas untuk mengamati proses pembelajaran secara langsung, terutama dalam pemilihan dan penggunaan metode, media yang digunakan dan keterlibatan siswa dalam proses pembelajaran. Dari hasil supervisi ini, dapat diketahui kelemahan sekaligus keunggulan guru dalam melaksanakan pembelajaran, tingkat penguasaan kompetensi guru yang bersangkutan, selanjutnya diupayakan solusi, pembinaan dan tindak lanjut tertentu sehingga guru dapat memperbaiki kekurangan yang ada sekaligus mempertahankan keunggulannya dalam melaksanakan pembelajaran.

Disampaikan oleh Rohmatillah, selaku guru mata pelajaran Aqidah Akhlak, yang menjelaskan bahwasanya;

"Penilaian yang dilakukan terhadap performa guru yang melaksanakan proses pembelajaran di kelas tidak asal-asalan. Dalam supervisi kita menggunakan instrumen standar proses kegiatan pembelajaran yang telah ditetapkan pada awal tahun ajaran yang sedang berjalan. Penilaian performa guru dimulai dari awal hingga penutup kegiatan pembelajaran. Selama berada di kelas, supervisor tidak memberikan komentar apapun terhadap performa guru, hanya menulis catatan yang diperlukan pada

\footnotetext{
${ }^{47}$ Imam Sauqi, wawancara, Silo 15 April 2015
} 
buku memonya. Setelah proses pembelajaran yang biasanya berlangsung selama dua jam pelajaran, barulah saat Kepala Madrasah dan si guru berada di kantor, mereka mendiskusikan catatan kecil Kepala Madrasah. Catatan tersebut berisi temuan yang didapat di kelas tadi selama proses belajar mengajar berlangsung, termasuk keadaan siswa selama belajar. Kepala Madrasah melakukan penilaian minimal satu kali dalam tiap semester untuk satu orang guru. Penilaian ini selanjutnya akan berguna untuk memberikan masukan terhadap pembinaan yang akan dilakukan Kepala Madrasah terhadap guru yang bersangkutan. Berdasarkan hasil penilaian yang diterima guru, maka guru akan melakukan perbaikan seperlunya terhadap kekurangan yang ia miliki. Perbaikan yang dilakukan oleh guru, akan diperiksa minimal dalam kurun waktu tiga bulan berikutnya". ${ }^{8}$

Hal senada disampaikan oleh bapak Abdul Wahid Hasyim pengampu mata pelajaran Matematika, bahwasanya:

"Dalam supervisi yang dilakukan oleh Kepala Madrasah disini tidak hanya kita di observasi, ditinjau, dinilai, dikritik saja, tetapi ada sebuah jalan keluar yang diupayakan untuk membantu kita, guru-guru, yaitu tindak lanjut yang sesuai dengan kebutuhan kita masing-masing guru. Misalnya, dari pelaksanaan supervisi diketahui kita kurang mampu merencanakan RPP, nah baginya diberikan pelatihan mengenai penyusunan perangkat pembelajaran. Dan yang paling banyak menjadi kendalan adalah pengelolaan kelas. Karena disini kebanyakan guru-guru masih belum banyak berpengalaman dalam kegiatan pembelajaran di kelas, ya maklum gurunya masih banyak yang muda dan baru, mungkin kalau teori di buku sudah bagus tapi pengalaman masih perlu banyak berlatih. Maka, Kepala Madrasahpun tidak segan langsung ikut menyiapkan kesiapan di kelas, seperti misalnya; salah seorang guru dalam RPPnya akan melaksanakan model pembelajaran tutor sebaya, disitu Kepala Madrasah langsung membimbing guru merancang tatanan bangku yang sesuai untuk menyiapkan kelas sebelum pelajaran dimulai". ${ }^{49}$

Supervisi akademik tidak bisa terlepas dari penilaian unjuk kerja guru dalam mengelola pembelajaran. Supervisi akademik merupakan serangkaian kegiatan membantu guru mengembangkan kemampuannya mengelola proses pembelajaran, sehingga dapat membawa dampak positif terhadap motivasi belajar siswa dan dapat meningkatkan mutu dari hasil belajar yang telah dilakukan. Maka menilai unjuk kerja guru dalam mengelola proses

\footnotetext{
${ }^{48}$ Rohmatillah, Wawancara, Silo, 7 Mei 2015

${ }^{49}$ Abdul Wahid Hasyim, Wawancara, Silo, 3 Juni 2015
} 
pembelajaran merupakan salah satu kegiatan yang tidak bisa dihindarkan prosesnya. Penilaian kinerja guru dalam mengelola proses pembelajaran sebagai suatu proses pemberian estimasi mutu kerja guru dalam mengelola proses pembelajaran, merupakan bagian integral dari serangkaian kegiatan supervisi akademik. Agar supervisi akademik dapat membantu guru mengembangkan kemampuannya, maka untuk pelaksanaannya terlebih dahulu perlu diadakan penilaian kemampuan guru, sehingga bisa ditetapkan aspek yang perlu dikembangkan dan cara mengembangkannya. Dari sini dapat dipaparkan hasil temuan pada fokus dua.

Temuan penelitian pada fokus ini yaitu: pertama, supervisi dilaksanakan dengan teknik kunjungan kelas, observasi kelas dan pertemuan individu. Kedua, Beberapa kemampuan guru muda dan guru baru masih minim dalam mengelola proses pembelajaran. Guru kesulitan melakukan apersepsi pada kegiatan pendahuluan, guru kesulitan menentukan metode serta media yang tepat untuk menjelaskan materi pada kegiatan ini dan guru kesulitan melakukan penilaian/evaluasi pada kegiatan penutup. Temuan penelitian diformulasikan dalam bentuk tabel, sebagai berikut:

Tabel 2: Temuan Penelitian

\begin{tabular}{|c|c|}
\hline Fokus 2 & Temuan Penelitian \\
\hline $\begin{array}{l}\text { Pelaksanaan supervisi } \\
\text { akademik kepala madrasah } \\
\text { dalam membantu } \\
\text { mengembangkan } \\
\text { kemampuan guru } \\
\text { mengelola proses } \\
\text { pembelajaran sebagai upaya } \\
\text { meningkatkan } \\
\text { profesionalisme guru untuk } \\
\text { memotivasi belajar siswa }\end{array}$ & $\begin{array}{l}\text { Supervisi dilaksanakan dengan } \\
\text { teknik kunjungan kelas, observasi } \\
\text { kelas dan pertemuan individu } \\
\text { Beberapa kemampuan guru muda } \\
\text { dan guru baru masih minim } \\
\text { dalam mengelola proses } \\
\text { pembelajaran. Guru kesulitan } \\
\text { melakukan apersepsi pada } \\
\text { kegiatan pendahuluan, guru } \\
\text { kesulitan menentukan metode } \\
\text { serta media yang tepat untuk } \\
\text { menjelaskan materi pada kegiatan } \\
\text { ini dan guru kesulitan melakukan } \\
\text { penilaian/evaluasi pada kegiatan } \\
\text { penutup. }\end{array}$ \\
\hline
\end{tabular}


Dalam proses pembelajaran guru memiliki peran sangat penting dan strategis dalam membimbing peserta didik ke arah kedewasaan, kematangan dan kemandirian, sehingga guru sering dikatakan sebagai ujung tombak pendidikan. Kedudukan dan peranan guru semakin bermakna strategis dalam mempersiapkan sumberdaya manusia yang berkualitas dalam menghadapi era global tugas guru dalam proses belajar-mengajar dapat dikelompokan ke dalam tiga kegiatan, yaitu: (1) menyusun program pengajaran, (2) menyajikan atau melaksanakan pengajaran, dan (3) melaksanakan evaluasi belajar. ${ }^{50}$

Kemampuan guru untuk mengelola proses belajar-mengajar dapat mendorong siswa untuk mengembangkan potensi yang dimilikinya. Perhatian pimpinan madrasah pada peningkatan kemampuan guru adalah sangat penting demi terwujudnya mutu pendidikan di madrasah. Rifai dalam Suryosubroto mengatakan bahwa: Di dalam situasi pengajaran, gurulah yang memimpin dan bertanggung jawab penuh atas kepemimpinan yang dilakukan. Ia tidak melakukan instruksi- instruksi dan tidak berdiri di bawah instruksi manusia lain kecuali dirinya sendiri, setelah masuk dalam situasi kelas. ${ }^{51}$

Dari penjelasan ini maka bisa dikatakan bahwa tugas guru sebagai ujung tombak pendidikan perlu mendapat perhatian serius dari pimpinan dengan memberikan bimbingan. Hal tersebut sebagaimana kegiatan pokok supervisi yaitu melakukan pembinaan kepada personil madrasah pada umumnya dan khususnya guru, agar kualitas pembelajaran dapat meningkat. Sebagai dampak dalam meningkatnya kualitas pembelajaran, diharapkan dapat pula meningkatkan prestasi belajar siswa. Dengan meningkatnya prestasi belajar siswa berarti meningkat pula kualitas lulusan. Sasaran akhir supervisi pendidikan yaitu terciptanya suasana pembelajaran yang memungkinkan peserta didik dapat mengembangkan potensinya secara optimal. Untuk mewujudkan hal tersebut, diperlukan pembinaan secara intensif bagi guruguru yang berkaitan dengan penataan kelas bernuansa PAKEM. Mengajar merupakan sesuatu yang kompleks, karena sasaran kegiatannya adalah manusia yang memiliki berbagai keunikan. Selain itu, berkaitan pula dengan pemanfaatan dan pengembangan iptek, seni dan budaya.

Sesuai dengan hal tersebut Sahertian menjelaskan sasaran supervisi akademik adalah pembinaan kurikulum, perbaikan proses pembelajaran, pengembangan staf dan pemeliharaan dan perawatan moral serta semangat kerja guru-guru..$^{2}$

Komponen yang mempengaruhi proses pembelajaran antara lain guru, siswa, kurikulum, alat dan buku pelajaran serta kondisi lingkungan dan fisik. Oleh sebab itu, fokus utama supervisi akademik adalah usaha-usaha yang

\footnotetext{
${ }^{50}$ Suryosubroto, B, Proses Belajar Mengajar di Sekolah (Jakarta: Rineka Cipta, 2002), 8

${ }^{51}$ Suryosubroto, B, Proses Belajar Mengajar, 4.

${ }^{52}$ Piet A. Sahertian, Konsep Dasar, 27.
} 
sifatnya memberikan kesempatan kepada guru untuk berkembang secara profesional sehingga mampu melaksanakan tugas pokoknya, yaitu: memperbaiki dan meningkatkan proses dan hasil pembelajaran. ${ }^{53}$

Berdasarkan pada teori tersebut, pelaksanaan supervisi akademik di MTs Muqoddimatul Akhlak dalam mengelola proses pembelajaran dalam peningkatan profesionalisme guru untuk memotivasi siswa dilakukan dengan teknik supervisi yang dibutuhkan disesuaikan dengan permasalahan yang terjadi, selain itu pemberian bimbingan dilakukan pada aspek mengelola proses pembelajaran dari tahap pembukaan, kegiatan inti dan kegiatan penutup.

Pada MTs Muqoddimatul Akhlak teknik supervisi yang digunakan adalah teknik individual, yaitu; kunjungan kelas, observasi kelas dan pertemuan individu. Hal ini diambil dikarenakan pada saat ini teknik itulah yang dinilai lebih tepat dan efektif serta efisien untuk diterapkan. Lebih dari itu untuk bisa menentukan teknik supervisi yang sesuai maka Kepala Madrasah dituntut untuk memiliki kompetensi sebagai supervisor.

Supervisor yang kompeten adalah supervisor yang mampu melaksanakan tugas dan kewajibannya secara efektif. Supervisi tersebut dapat dilaksanakan melalui beberapa metode atau teknik. Teknik tersebut dibedakan antara yang bersifat individual dan kelompok, teknik individual meliputi kunjungan kelas, observasi kelas dan pertemuan individu, sedangkan teknik kelompok terdiri dari kepanitian-kepanitian, kerja kelompok, laboratorium kurikulum, baca terpimpin, darmawisata, kuliah/studi, diskusi panel, perpustakaan jabatan, organisasi profesional, bulletin supervisi, pertemuan guru, lokakarya dan konferensi kelompok. ${ }^{54}$

\section{Pelaksanaan supervisi akademik kepala madrasah dalam membimbing perilaku mengajar guru sebagai upaya meningkatkan profesionalisme guru untuk memotivasi belajar siswa MTs Muqoddimatul Akhlak Curah Wungkal Silo Jember.}

Kepala Madrasah sebagai pemimpin suatu lembaga mempunyai tugas membantu guru, memberikan stimulus dan mendorong guru untuk selalu bertingkah yang baik yang diidealkan, karena Kepala Madrasah adalah penggerak dalam pelaksanaan pendidikan dan pembelajaran. Kepala Madrasah penentu keberhasilan generasi yang sesuai dengan harapan bangsa dan orang tua. Sebagai supervisor kepala madrasah dituntut untuk bisa membimbing perilaku guru, berakhlak mulia, arif, dan berwibawa serta menjadi teladan peserta didik.

${ }^{53}$ Direktorat Jenderal Peningkatan Mutu Pendidik Dan Tenaga Kependidikan, Supervisi Akademik, 17.

${ }^{54}$ Lantip Diat Prasojo dan Sidiyono, Supervisi, 101 


\section{bahwasanya: \\ Bapak Imam Sauqi sebagai Kepala Madrasah menyampaikan,}

"Di dalam proses pembelajaran, guru memegang peranan yang sangat penting. Untuk hasil yang maksimal dari peran guru, guru perlu dicermati perilakunya, baik yang sehari-hari ataupun yang diidealkan. Sikap dan perilaku guru berbeda-beda. Hal ini karena sikap dan perilaku guru dalam proses pembelajaran atau diluar pembelajaran dipengaruhi oleh keunikan guru. Lebih lanjut lagi kepala madrasah menyatakan bahwa perilaku sebagai manifestasi hidup kejiwaan yang didorong oleh motif tertentu, hingga manusia itu berperilaku atau berbuat. Ya dari sini saya sebagai Kepala Madrasah disetiap kesempatan selalu mengingatkan dan menghimbau kepada semua guru untuk berperilaku baik terhadap semua siswa. Dan tentunya, tidak hanya dengan kata-kata saja, tetapi juga dengan memberikan contoh akhlak yang baik dalam keseharian. Kaitannya, dengan supervisi, kita harus memahami dulu sampai dimana kemampuan guru tersebut. Sehingga nanti ketika saya melakukan supervisi, perlakuan dan bimbingan yang diberikan kepada guru bisa efektif, tepat. Karena tidak semua guru mempunyai kemampuan yang sama, ada yang kemampuannya dibawah, sedang sampai tinggi. Sama juga seperti siswa mereka mempunyai kemampuan yang beragam, dan perlakuan gurupun terhadap siswa juga harus beragam, tidak boleh semuanya disama-ratakan. Kalau kita bisa memahami perilaku guru, nanti akan lebih mudah bagi kita memberikan arahan". ${ }^{55}$

Senada dengan pendapat Kepala Madrasah, waka kurikulum Bapak Moh. Hasan Basri mengatakan, bahwasanya :

"Perilaku atau aktivitas yang ada pada individu guru itu tidak timbul dengan sendirinya, tetapi sebagai akibat dari stimulus yang diterima oleh guru yang bersangkutan baik stimulus eksternal maupun stimulus internal. Kalau bersangkutan dengan perilaku, ya Kepala Madrasah disini selalu mengingatkan kami ketika rapat bulanan dirumah guru-guru dan ketika ngobrol waktu istirahat beliau juga menyelipkan tentang perilaku yang seharuskan kita lakukan. Beliaupun juga selalu berperilaku santun sebagai contoh yang baik bagi guru-guru ketika berinteraksi dengan anak didik". ${ }^{56}$

Ansorullah selaku waka kesiswaan juga mengatakan hal yang serupa, sebagaimana kutipan hasil wawancara berikut:

"Perilaku kita sehari-hari baik diluar proses pembelajaran lebih-lebih ketika proses pembelajaran merupakan salah satu yang diperhatikan

\footnotetext{
${ }^{55}$ Imam Sauqi, Wawancara, Silo, 7 April 2015.

${ }^{56}$ Moh. Hasan Basri, Wawancara, Silo, 7 April 2015
} 
oleh Kepala Madrasah, ketika Kepala Madrasah sudah mensupervisi, kita dipanggil keruangannya dan diberi arahan terhadap kekurangan kita ketika proses pembelajaran berlangsung, lebih-lebih perilaku kita terhadap siswa harus memperlakukan mereka sebagai anak kita sendiri agar mereka senang belajar dan tidak canggung menanyakan materi yang kita sampaikan ketika mereka belum paham". ${ }^{77}$

Pemahaman terhadap perilaku guru diharapkan pengembangan kompetensi profesional guru-guru semakin efektif, sehingga tujuan pendidikan yaitu terwujudnya sumber daya manusia yang bermutu tinggi dapat dicapai. Diharapkan pula guru tampil sebagai modeling dalam pengembangan karakter peserta didik sehingga jati diri bangsa tetap terjaga dengan baik.

Pelaksanaan supervisi akademik, kepala madrasah MTs Muqoddimatul Akhlak menyadari bahwa setiap madrasah memiliki tingkat perkembangan guru-guru yang bervariasi mulai dari yang rendah, sedang sampai tinggi prestasinya, sehingga tidak mudah kepala madrasah dalam melaksanakan supervisi akademik secara efektif. Supervisor harus memperhatikan tingkat perkembangan masing-masing guru sehingga dapat ditentukan perilaku yang cocok bagi guru tersebut. Hal ini dimaksudkan agar supervisor tidak mengalami kesulitan dalam menghadapi guru sebab mereka sudah dipahami perilakunya. Supervisor akan mengalami kesulitan jika semua guru disamakan strateginya baik guru yang berada pada kuadran I,II, dan III maupun yang berada pada kuadran IV (guru profesional). Supervisor sebagai gurunya guru dituntut memperluas wawasannya dalam membimbing guru, seperti halnya seorang guru dapat mempengaruhi perkembangan perilaku peserta didiknya. Dari sini dapat dipaparkan hasil temuan pada fokus tiga.

Temuan penelitian pada fokus ini yaitu; pertama, Kepala madrasah senantiasa mengingatkan dan memberi contoh perilaku yang baik kepada para guru dengan teknik supervisi penilaian diri sendiri dan pertemuan individu. Kedua, Perilaku mengajar guru untuk menjadi guru profesional dipengaruhi oleh kemauan dan kesungguhan guru untuk mengembangkannya. Temuan penelitian diformulasikan dalam bentuk tabel, sebagai berikut:

Tabel 3: Temuan Penelitian

\begin{tabular}{|l|c|}
\hline Fokus 3 & Temuan Penelitian \\
\hline
\end{tabular}

\footnotetext{
${ }^{57}$ Ansorullah, Wawancara, Silo, 10 April 2015.
} 


\begin{tabular}{|l|l|}
\hline \multicolumn{1}{|c|}{ Fokus 3 } & \multicolumn{1}{|c|}{ Temuan Penelitian } \\
\hline $\begin{array}{l}\text { Pelaksanaan supervisi } \\
\text { akademik kepala madrasah } \\
\text { dalam membimbing perilaku } \\
\text { mengajar guru sebagai upaya } \\
\text { meningkatkan } \\
\text { profesionalisme guru untuk } \\
\text { memotivasi belajar siswa }\end{array}$ & $\begin{array}{l}\text { Kepala madrasah senantiasa } \\
\text { mengingatkan dan memberi contoh } \\
\text { dengan teknik supervisi penilaian } \\
\text { diri sendiri dan pertemuan individu. }\end{array}$ \\
\cline { 2 - 2 } & $\begin{array}{l}\text { Perilaku mengajar guru untuk } \\
\text { menjadi guru profesional } \\
\text { dipengaruhi oleh kemauan dan } \\
\text { kesungguhan guru untuk } \\
\text { mengembangkannya }\end{array}$ \\
\hline
\end{tabular}

kepala Madrasah juga dituntut untuk memiliki sejumlah kompetensi untuk menopang kinerjanya sebagaimana disebutkan dalam Peraturan Menteri Pendidikan Nasional (Permendiknas) nomor 13 tahun 2007 tentang Standar Kepala Sekolah/Madrasah bahwa kompetensi yang harus dikuasai kepala madrasah meliputi kompetensi kepribadian, kompetensi manajerial, kompetensi kewirausahaan, kompetensi sosial dan kompetensi supervisi. ${ }^{58}$

Kompetensi supervisi akademik kepala madrasah merupakan aspek yang paling strategis karena bersentuhan langsung dengan kompetensi profesional guru. Menurut Alfonso sebagaimana dikutib oleh Abd. Kadim Masaong menyatakan perilaku siswa sangat dipengaruhi oleh perilaku guru, sedangkan perilaku guru dalam pembelajaran sangat dipengaruhi oleh perilaku kepala madrasah, yang dalam hal ini adalah sebagai supervisor..$^{59}$ Glickman membagi karakteristik guru atas dua tingkatan atau level, yaitu tingkatan komitmen (level of commitment) dan tingkatan abstraksi (level of abstraction). Kedua level ini membentuk perilaku guru dalam mengembangkan diri dan dalam melaksanakan pembelajaran di kelas. Level abstraksi merujuk pada kemampuan kognitif, sedangkan level komitmen merujuk pada kesungguhan untuk menjalankan tugas-tugas yang diemban.

Penjelasannya sebagaimana dikutip dalam buku metode dan teknik supervisi, bahwasanya ada empat prototipe guru dalam mengelola proses pembelajaran. Proto tipe guru yang terbaik, menurut teori ini, adalah guru prototipe profesional. Seorang guru bisa diklasifikasikan ke dalam prototipe

\footnotetext{
${ }^{58}$ Permendiknas nomor 13 tahun 2007 Tentang Standar kepala sekolah/Madrasah.

${ }^{59}$ Abd. Kadim Masaong, Supervisi Pembelajaran, 53
} 
profesional apabila ia memiliki kemampuan tinggi (high level of abstract) dan motivasi kerja tinggi (high level of commitment).

Penjelasan di atas memberikan implikasi khusus kepada apa seharusnya program supervisi akademik. Supervisi akademik yang baik harus mampu membuat guru semakin kompeten, yaitu guru semakin menguasai kompetensi, baik kompetensi kepribadian, kompetensi pedagogik, kompetensi profesional, dan kompetensi sosial. Oleh karena itu supervisi akademik harus menyentuh pada pengembangan seluruh kompetensi guru termasuk dalam aspek perilaku.

\section{Kesimpulan}

Berdasarkan uraian tersebut maka diperoleh kesimpulan dari penelitian ini sebagai berikut: (1) Pelaksanaan supervisi akademik kepala madrasah dalam membantu guru menyusun rencana pembelajaran sebagai upaya meningkatkan profesionalisme guru untuk memotivasi belajar siswa Mts Muqoddimatul Akhlak Curah Wungkal Silo Jember, yaitu semua guru diwajibkan membuat Rencana pembelajaran, semua guru diberikan kesempatan untuk melakukan konsultasi/bimbingan, telah terjadwal dalam rencana program supervisi kepala madrasah dengan teknik pertemuan individu, dengan proses awal memeriksa RPP guru yang akan disupervisi, memberikan penilaian terhadap RPP dan memberikan saran revisi jika diperlukan untuk perbaikan perangkat pembelajaran selanjutnya (2) Pelaksanaan supervisi akademik kepala madrasah dalam membantu mengembangkan kemampuan guru mengelola proses pembelajaran sebagai upaya meningkatkan profesionalisme guru untuk memotivasi belajar siswa Mts Muqoddimatul Akhlak Curah Wungkal Silo Jember, yaitu Kepala Madrasah melakukan supervisi dengan teknik kunjungan kelas, observasi kelas dan pertemuan individu. Penilaian pengelolaan pembelajaran yang dilakukan oleh Kepala Madrasah adalah proses pembelajaran di kelas yang meliputi: kegiatan pendahuluan, kegiatan inti dan kegiatan penutup (3) Pelaksanaan Supervisi Akademik Kepala Madrasah dalam Membimbing Perilaku Mengajar Guru sebagai Upaya Meningkatkan Profesionalisme Guru untuk Memotivasi Belajar Siswa Mts Muqoddimatul Akhlak Curah Wungkal Silo Jember yaitu Kepala madrasah senantiasa mengingatkan dan memberi contoh perilaku yang baik kepada para guru dengan teknik supervisi penilaian diri sendiri dan pertemuan individu. Adapun Perilaku mengajar guru untuk menjadi guru profesional dipengaruhi oleh kemauan dan kesungguhan guru untuk mengembangkannya 


\section{Daftar Pustaka}

Arikunto, Suharsimi. 2006. Dasar-Dasar Supervisi. Jakarta: PT. Rineka Cipta.

Direktorat Tenaga Kependidikan Direktorat Jenderal Peningkatan Mutu Pendidik Dan Tenaga Kependidikan Departemen Pendidikan Nasional. 2008. Metode Dan Teknik Supervisi. Jakarta: Ditjen PMPTK.

Masaong, Abd. Kadim. 2003. Supervisi Pembelajaran dan Pengembangan Kapasitas Guru Memberdayakan Pengawas sebagai Gurunya Guru. Bandung: CV.Alfabeta.

Minarti, Sri. 2011. Manajemen Sekolah. Jogjakarta: Ar-Ruzz Media.

Mulyasa, E. 2006. Menjadi Kepala Sekolah Profesional. Bandung: PT. Remaja Rosda Karya.

Peraturan Menteri Pendidikan Nasional (Permendiknas) No. 13 Tahun 2007. PP Nomor 41 tahun 2007 tentang Standar Proses

Peraturan Menteri Pendidikan Nasional (Permendiknas) No. 13 Tahun 2007

Peraturan Pemerintah Nomor 19 Tahun 2005 tentang Standar Pendidikan Nasional

Permendiknas nomor 13 tahun 2007 Tentang Standar kepala sekolah/Madrasah.

Rodliyah, St. 2014. Supervisi Pendidikan dan Pembelajaran. Jember: STAIN Jember Press.

Sahertian, Piet A. 2008. Konsep Dasar dan Teknik Supervisi Pendidikan dalam Rangka Pengembangan Sumber Daya Manusia. Jakarta: PT. Rineka Cipta.

Prasojo, Lantip Dian dan Sudiyono, 2011. Supervisi Pendidikan. Yogyakarta: Gava Media

Suryosubroto. 2002. Proses Belajar Mengajar di Sekolah. Jakarta: Rineka Cipta.

Tim Penyusun. 2003. Standar Supervisi \& Evaluasi Pendidikan: Supervisi Akademikdan Evaluasi Program. Jakarta: Depag RI 